Article

\title{
Electrochemical Synthesis of Zirconium Pre-Catalysts for Homogeneous Ethylene Oligomerization
}

\author{
Giyjaz E. Bekmukhamedov 1,2,*, Aleksandr V. Sukhov ${ }^{1,2}$, Aidar M. Kuchkaev ${ }^{1,2}$, \\ Khasan R. Khayarov ${ }^{1}$, Alexander V. Gerasimov ${ }^{1}$, Irina V. Vasilenko ${ }^{3}$, Sergei V. Kostjuk ${ }^{3,4,5}$ (D) \\ and Dmitry G. Yakhvarov $1,2, * \mathbb{D}$
}

1 Alexander Butlerov Institute of Chemistry, Kazan Federal University, 18 Kremlevskaya st., Kazan 420008, Russia; alex.suhoff@rambler.ru (A.V.S.); kuchkaev95@mail.ru (A.M.K.); khayarov.kh@mail.ru (K.R.K.); alexander.gerasimov@kpfu.ru (A.V.G.)

2 Arbuzov Institute of Organic and Physical Chemistry, FRC Kazan Scientific Center of RAS, 8 Arbuzov st., Kazan 420088, Russia

3 Research Institute for Physical Chemical Problems of the Belarusian State University, 14 Leningradskaya st., Minsk 220006, Belarus; vasilenkoi@bsu.by (I.V.V.); kostjuks@bsu.by (S.V.K.)

4 Department of Chemistry, Belarusian State University, 14 Leningradskaya st., Minsk 220006, Belarus

5 Institute for Regenerative Medicine, Sechenov University, 8-2 Trubetskaya st., Moscow 119991, Russia

* Correspondence: gbekmouk@kpfu.ru (G.E.B.); yakhvar@iopc.ru (D.G.Y.);

Tel.: +7-843-2337416 (G.E.B.); Fax: +7-843-2732253 (D.G.Y.)

Received: 14 November 2019; Accepted: 9 December 2019; Published: 12 December 2019

\begin{abstract}
The catalytic activity of electrochemically synthesized zirconium carboxylates was studied in the process of ethylene oligomerization. Zirconium carboxylates were electrochemically synthesized directly from metallic zirconium and corresponding carboxylic acids (acetic, octanoic and lauric). A comprehensive study (element analysis, nuclear magnetic resonance (NMR) and infrared (IR) spectroscopy, powder X-ray diffraction (PXRD)) of the synthesized zirconium carboxylates showed that these species contain bidentate carboxylate moieties. It was shown that obtained zirconium carboxylates, in combination with $\mathrm{Et}_{3} \mathrm{Al}_{2} \mathrm{Cl}_{3}(\mathrm{Al} / \mathrm{Zr}=20)$, have a moderate activity of (7.6-9.9) $\times$ $10^{3} \mathrm{~mol}_{\mathrm{C} 2 \mathrm{H} 4} \cdot \mathrm{mol}_{\mathrm{Zr}}{ }^{-1} \cdot \mathrm{h}^{-1}$ in terms of ethylene oligomerization (at $\mathrm{T}=80^{\circ} \mathrm{C}, \mathrm{p}=20 \mathrm{bar}$ ), leading to even-numbered $\mathrm{C}_{4}-\mathrm{C}_{10}$ linear alpha-olefins.
\end{abstract}

Keywords: electrochemical synthesis; zirconium carboxylate; ethylene oligomerization; pre-catalyst; linear alpha-olefins

\section{Introduction}

The continuous growth of global polymer production leads to the development of new methods and catalysts for obtaining of olefin monomers; for example, alkane dehydrogenation, methanol-to-olefins, metathesis and olefin oligomerization [1-5]. In its turn, ethylene oligomerization aimed to obtain linear alpha-olefins (LAO), which are used as co-monomers in the production of the demanded types of polyethylene (linear low-density polyethylene, high-density polyethylene), as well as for the production of a wide range of unique chemicals, such as lubricants and additives, plasticizers, surfactants and so forth [6].

From the development of the Ziegler-Natta catalytic system to the present time, zirconium organometallic compounds have been widely investigated in the context of their use as pre-catalysts (substances that acquire catalytic properties after activation) in the reactions of the oligomerization and polymerization of unsaturated hydrocarbons [4,7-12]. For example, zirconium pre-catalysts are used in many industrial processes of homogeneous ethylene oligomerization, such as Alphaselect (IFP Energies Nouvelles, Rueil-Malmaison Cedex, France), Alpha-Sablin (SABIC-Linde, Munich, Germany) 
and the process of Idemitsu Kosan Co. Ltd (Tokyo, Japan) [10-12]. The products of these processes are even-numbered LAOs with a wide distribution regarding the number of carbon atoms (from 4 to $30-40)$.

Usually, the main precursor for zirconium catalysts is zirconium tetrachloride [13-17]. However, the disadvantage of using this reagent is connected to its high hygroscopicity and, as a result, its low air resistance, as well as the release of hydrogen chloride during the preparation of the pre-catalyst, which negatively affects the nature environment. The use of the electrochemical synthesis of zirconium carboxylates will not only exclude the release of $\mathrm{HCl}$ but will also reduce the energy costs. Therefore, the elaboration of new methods for the preparation of $\mathrm{Zr}$-based pre-catalysts is of high interest.

Herein we present the results of the electrochemical synthesis of zirconium carboxylates directly from a metal and the corresponding acid, which are efficient pre-catalysts for ethylene oligomerization.

\section{Results and Discussion}

The traditional method of zirconium carboxylate synthesis is highly energy-consuming. It involves the prolonged boiling of zirconium tetrachloride in carboxylic acid or its solution [18-22]. A direct electrochemical method for the preparation of transition metal carboxylates in mild and ecologically safe conditions is currently known [23]; however, this example is limited by di- and trivalent 3D-metals $(\mathrm{Cr}, \mathrm{Mn}, \mathrm{Fe}, \mathrm{Co}, \mathrm{Ni}, \mathrm{Cu}$ ). We have tried to use a similar approach for the synthesis of zirconium carboxylates with a variety of carboxylic acids bearing a wide range of carbon atoms in hydrocarbon chain (acetate, octanoate, laurate). The choice of these compounds was based on their usage as a pre-catalyst in an important industrial process of LAO synthesis-Alpha-Sablin (SABIC-Linde) [11] —as well as due to their use for the synthesis of materials with unique properties, such as metal-organic frameworks and catalysts [24-26].

\subsection{Cyclic Voltammetry}

The electrochemical system which was planned to be used in electrosynthesis was investigated by cyclic voltammetry (Figure 1). The following electrodes were used: working electrode-zirconium plate; reference electrode-silver electrode $\mathrm{Ag} / \mathrm{AgNO}_{3}\left(0.01 \mathrm{~mol} \cdot \mathrm{L}^{-1}\right.$ solution in acetonitrile); auxiliary electrode-platinum wire.

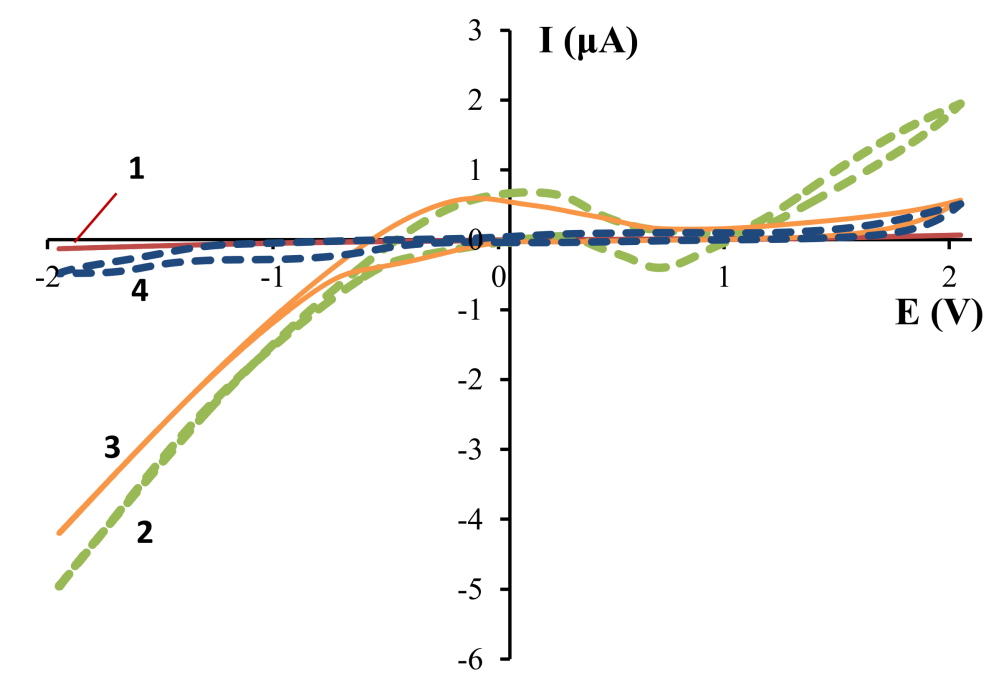

Figure 1. Cyclic voltammograms, recorded on a Zr-working electrode in an acetonitrile solution of acetic acid (1), acetic acid $+\mathrm{Et}_{4} \mathrm{NCl}(2)$, acetic acid $+{ }^{\mathrm{n}} \mathrm{Bu}_{4} \mathrm{NBF}_{4}(3),{ }^{n} \mathrm{Bu}_{4} \mathrm{NBF}_{4}$ (4) (concentrations of acetic acid and supporting salt are $1.20 \mathrm{~mol} \cdot \mathrm{L}^{-1}$ and $0.01 \mathrm{~mol} \cdot \mathrm{L}^{-1}$, respectively). 
The voltammetric scanning of an acetic acid solution showed that the anodic and cathodic currents are close to 0 (curve 1, Figure 1). With the addition of $\mathrm{Et}_{4} \mathrm{NCl}$-supporting salt, the anodic and cathodic current increased significantly (up to 5 and $2 \mu \mathrm{A}$, respectively) and a shoulder in the $(-0.5-0.5 \mathrm{~V}$ ) region and a negative signal in the $(0.3-1.0 \mathrm{~V})$ region appeared (curve 2, Figure 1$)$. The significant increase in the cathodic current is probably due to a shift in the equilibrium of the acetic acid dissociation to the right by $\mathrm{Et}_{4} \mathrm{~N}^{+}$ions, which accumulated near the cathode, and subsequent hydrogen sorption and reduction at the $\mathrm{Zr}$-cathode. The increased anodic current indicates the surface interaction of zirconium with dissociated acetic acid.

The shoulder in the transition $(-0.5-0.5 \mathrm{~V})$ region is probably due to desorption from the electrode of hydrogen, which reduced at more negative potentials. This assumption is confirmed by an increase in the intensity of this signal with acetic acid concentration (Figure 2). The negative signal in the anodic $(0.3-1.0 \mathrm{~V})$ region also became more pronounced with acetic acid concentration. This signal is probably due to the product of the interaction between zirconium and acetic acid.

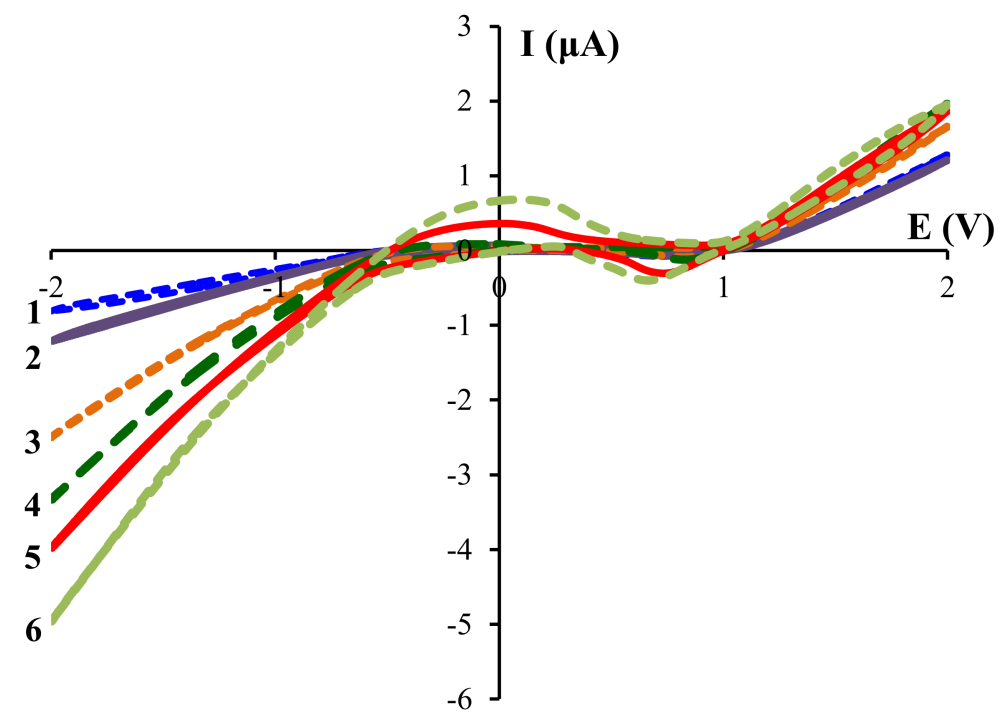

Figure 2. Cyclic voltammograms, recorded for different acetic acid concentrations, $\mathrm{mol} \cdot \mathrm{L}^{-1}: 1$,

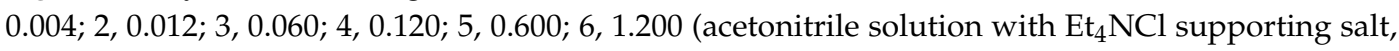
$\left.0.01 \mathrm{~mol} \cdot \mathrm{L}^{-1}\right)$.

The replacement of the $\mathrm{Et}_{4} \mathrm{NCl}$-supporting salt by ${ }^{\mathrm{n}} \mathrm{Bu}_{4} \mathrm{NBF}_{4}$ is accompanied by a decrease in the anode current (curve 3, Figure 1). This may indicate that the electrochemical interaction of acetic acid with the zirconium anode is realized by the preliminary formation of the $\mathrm{Zr}-\mathrm{Cl}$ bond (Equations (1)-(3)).

$$
\begin{gathered}
\mathrm{Et}_{4} \mathrm{NCl} \leftrightarrow \mathrm{Et}_{4} \mathrm{~N}^{+}+\mathrm{Cl}^{-} \\
\equiv \mathrm{Zr}^{\delta+}(\text { anode })+\mathrm{nCl}^{-} \rightarrow \equiv \mathrm{Zr}^{(\delta-\mathrm{n})+} \mathrm{Cl}_{\mathrm{n}}(\text { surface }) \\
\equiv \mathrm{Zr}^{(\delta-\mathrm{n})+} \mathrm{Cl}_{\mathrm{n}}+\mathrm{nCH}_{3} \mathrm{COO}^{-} \rightarrow \equiv \mathrm{Zr}^{\delta+}+\mathrm{Zr}\left(\mathrm{CH}_{3} \mathrm{COO}\right)_{\mathrm{n}}+\mathrm{nCl}^{-}
\end{gathered}
$$

Equations (1)-(3). Proposed mechanism of interaction between the $\mathrm{Zr}$-anode and carboxylate ions. At the same time, the current at the zirconium cathode is nearly constant (curve 3, Figure 1), which also may be due to the shift of the equilibrium of acetic acid dissociation in the presence of ${ }^{\mathrm{n}} \mathrm{Bu}_{4} \mathrm{~N}^{+}$.

The relatively high value of the anode current in the presence of the ${ }^{n} \mathrm{Bu}_{4} \mathrm{NBF}_{4}$ might be due to the anodic oxidation of $\mathrm{BF}_{4}^{-}$ions rather than the interaction of acetic acid with zirconium. This assumption is confirmed by the preservation of the anodic current in the absence of acetic acid (curve 4, Figure 1). The oxidation of $\mathrm{BF}_{4}{ }^{-}$ions to $\mathrm{BF}_{3}, \mathrm{~F}_{2}, \mathrm{~B}_{2} \mathrm{~F}_{7}{ }^{-}$on a platinum anode was observed in Reference [27]. 
It should be noted that, for solutions with octanoic $\left(\mathrm{C}_{7} \mathrm{H}_{15} \mathrm{COOH}\right)$ and lauric acid $\left(\mathrm{C}_{11} \mathrm{H}_{23} \mathrm{COOH}\right)$, similar voltammograms and regularities were also observed (see Supplementary Materials).

Thus, cyclic voltammetry studies showed the possibility of the interaction between zirconium metal and carboxylic acid under electrochemical conditions in the presence of a supporting salt, which contains chloride anion.

\subsection{Electrosynthesis}

The electrochemical synthesis of zirconium carboxylates was carried out in an electrochemical cell without separation of the anodic and cathodic compartments, without the thermostating and stirring of the electrolyte. Zirconium plates were used as the anode and cathode. The conditions and characteristics of electrochemical synthesis are shown in Table 1.

Table 1. Conditions and results of the electrochemical synthesis of zirconium carboxylates from the corresponding acids. ${ }^{1 .}$

\begin{tabular}{|c|c|c|c|c|c|c|c|c|c|}
\hline Entry & Acid & $\underset{\text { (g) }}{\mathrm{m}_{\text {acid }}}$ & $\mathrm{U}(\mathrm{V})$ & $\begin{array}{l}\mathrm{I}_{\text {avg }}{ }^{2} \\
(\mathrm{~mA})\end{array}$ & $\begin{array}{c}\tau^{3} \\
(\mathrm{~min})\end{array}$ & $\begin{array}{c}\mathrm{Q}^{4} \\
(\mathrm{~A} \times \min )\end{array}$ & $\begin{array}{c}\mathrm{j}_{\mathrm{A}}{ }^{5} \\
\left(\mathrm{~mA} \times \mathrm{cm}^{-2}\right)\end{array}$ & $\mathrm{m}_{\text {prod }}{ }^{6}$ & $\begin{array}{c}\text { Yield }^{7} \\
(\%)\end{array}$ \\
\hline 1 & $\mathrm{CH}_{3} \mathrm{COOH}$ & 1.05 & 80 & 43 & 120 & 5.1 & 8 & 0.14 & n.d. \\
\hline 2 & $\mathrm{CH}_{3} \mathrm{COOH}$ & 2.10 & 80 & 51 & 160 & 8.8 & 10 & 0.29 & 75 \\
\hline 3 & $\mathrm{C}_{7} \mathrm{H}_{15} \mathrm{COOH}$ & 1.80 & 70 & 31 & 320 & 9.9 & 6 & 0.70 & 94 \\
\hline 4 & $\mathrm{C}_{12} \mathrm{H}_{25} \mathrm{COOH}$ & 0.11 & 80 & 43 & 35 & 1.6 & 8 & 0.07 & 59 \\
\hline $5^{8}$ & $\mathrm{CH}_{3} \mathrm{COOH}$ & 2.10 & 70 & 59 & 135 & 8.0 & 12 & 0.35 & n.d. \\
\hline $6^{9}$ & $\mathrm{CH}_{3} \mathrm{COOH}$ & 2.10 & 110 & 57 & 195 & 11.1 & 11 & 0.39 & n.d. \\
\hline $7^{10}$ & $\mathrm{CH}_{3} \mathrm{COOH}$ & 2.10 & 80 & 28 & 80 & 2.2 & 6 & - & - \\
\hline
\end{tabular}

${ }^{1}$ Solvent-acetonitrile, $10 \mathrm{~mL}$; supporting salt $\mathrm{Et}_{4} \mathrm{NCl}$, concentration $0.010 \mathrm{~mol} \cdot \mathrm{L}^{-1} .{ }^{2} \mathrm{I}_{\text {avg, }}$, average current.

${ }^{3} \tau$, electrolysis time. ${ }^{4} \mathrm{Q}$, amount of current. ${ }^{5} \mathrm{j}_{\mathrm{A}}$, anode current density. ${ }^{6} \mathrm{~m}_{\text {prod }}$, product weight. ${ }^{7}$ The yield was calculated on the basis of the zirconium content in the product and the amount of the current passed through electrolyte. ${ }^{8} \mathrm{Me}_{4} \mathrm{NBr}$ was used as the supporting salt, concentration $0.015 \mathrm{~mol} \cdot \mathrm{L}^{-1} \cdot{ }^{9} \mathrm{Et}_{4} \mathrm{NI}$ was used as the supporting salt, concentration $0.010 \mathrm{~mol} \cdot \mathrm{L}^{-1} ;{ }^{10} \mathrm{n}_{4} \mathrm{NBF}_{4}$ was used as the supporting salt, concentration $0.010 \mathrm{~mol} \cdot \mathrm{L}^{-1}$. N.d., not determined.

After $120 \mathrm{~min}$ of electrolysis of the solution containing $1.0 \mathrm{~mL}$ of acetic acid, $10 \mathrm{~mL}$ of acetonitrile and $16 \mathrm{mg}$ of $\mathrm{Et}_{4} \mathrm{NCl}$, yellow coloration occurred (entry 1, Table 1). A similar color change was observed when the current was passed through the electrolyte without acetic acid. This indicates the interaction of zirconium with acetonitrile or supporting salt, which may cause the contamination of the obtained carboxylate. To prevent the interaction, an excess of acid was used, which allowed us to carry out electrolysis until the precipitate was formed. Electrolysis was stopped when the current decreased to $10 \mathrm{~mA}$ due to the anode being covered by the precipitate. As a result of the electrolysis of acetic acid solution, a white powder was obtained; for octanoic acid solution, a yellow viscous liquid at the bottom of the cell was obtained (entries 2 and 3 respectively, Table 1).

Lauric acid concentration in the electrolyte was limited by its solubility in acetonitrile. In this case, the least amount of product was formed (entry 4, Table 1). The reason for this may be not only the low solubility of the starting acid but also the rapid covering of the anode by the product (white plastic mass) due to the large size of its molecules and therefore their low mobility.

To confirm the determining role of the halide anion in the interaction of zirconium with carboxylic acid, electrolysis of acetic acid solution with supporting salts containing halides $\left(\mathrm{Br}^{-}\right.$, $\left.\mathrm{I}^{-}\right)$and tetrafluoroborate $\left(\mathrm{BF}_{4}{ }^{-}\right)$was performed. If $\mathrm{Me}_{4} \mathrm{NBr}$ and $\mathrm{Et}_{4} \mathrm{NI}$ were used as the supporting salt, the precipitate also formed during the electrolysis (entries 5 and 6, Table 1). It should be noted that the resulting substances had a light beige color, probably due to the presence of residual bromine and iodine.

When ${ }^{n} \mathrm{Bu}_{4} \mathrm{NBF}_{4}$ was used, no precipitate formed (entry 7, Table 1). The current gradually decreased as a result of the deposit formation on the electrodes. There was no precipitation from electrolyte even $12 \mathrm{~h}$ after the electrolysis. This confirms the crucial role of halogen in the electrosynthesis of zirconium carboxylates. 
From the analysis of the electrochemical product composition (Table 2) it can be concluded that the obtained substances are not stoichiometric zirconium carboxylates-[ $\left.\operatorname{Zr}(\mathrm{RCOO})_{\mathrm{X}}\right](3<\mathrm{x}<$ 4). This is indicated by the zirconium content, which is higher than the theoretical value for the $\mathrm{Zr}(\mathrm{RCOO})_{4}$. This may be due to the formation of polymer structures with additional bonds between zirconium atoms $[20,28]$. Electrochemically synthesized zirconium acetate $\left[\mathrm{Zr}(\mathrm{Ac})_{\mathrm{x}}\right]\left(\mathrm{Ac}=\mathrm{CH}_{3} \mathrm{COO}\right)$ does not contain chlorine, while octanoate $\left[\mathrm{Zr}(\mathrm{Oct})_{\mathrm{x}}\right]\left(\mathrm{Oct}=\mathrm{C}_{7} \mathrm{H}_{15} \mathrm{COO}\right)$ and laurate $\left[\mathrm{Zr}(\mathrm{Laur})_{\mathrm{x}}\right]$ (Laur $=\mathrm{C}_{11} \mathrm{H}_{23} \mathrm{COO}$ ) contain $0.4-0.5 \mathrm{wt} \%$ chlorine, which corresponds to a molar ratio of $\mathrm{Zr} / \mathrm{Cl}=16-18$. This confirms that $\mathrm{Cl}^{-}$ions play the role of mediators during electrosynthesis.

Table 2. Carbon, hydrogen, zirconium and chlorine content in the products of electrosynthesis.

\begin{tabular}{cccccc}
\hline \multirow{2}{*}{ Acid } & \multicolumn{4}{c}{ Experimental (Calculated for $\left.\mathbf{Z r}(\mathbf{R C O O})_{4}\right)$ Content, wt\% } \\
\cline { 3 - 5 } & & $\mathbf{C}$ & $\mathbf{H}$ & $\mathbf{Z r}$ & $\mathbf{C l}$ \\
\hline 1 & $\mathrm{CH}_{3} \mathrm{COOH}$ & $28.0(29.4)$ & $4.6(3.7)$ & $32.0(27.9)$ & - \\
2 & $\mathrm{C}_{7} \mathrm{H}_{15} \mathrm{COOH}$ & $51.0(57.9)$ & $8.4(9.1)$ & $18.9(13.7)$ & 0.4 \\
3 & $\mathrm{C}_{12} \mathrm{H}_{25} \mathrm{COOH}$ & $51.1(64.9)$ & $8.5(10.4)$ & $18.7(10.3)$ & 0.5 \\
\hline
\end{tabular}

\subsection{Nuclear Magnetic Resonance Spectroscopy}

The products of electrosynthesis were studied by ${ }^{1} \mathrm{H}$ and ${ }^{13} \mathrm{C}\left\{{ }^{1} \mathrm{H}\right\} \mathrm{NMR}$ spectroscopy in $\mathrm{CDCl}_{3}$ as a solvent.

On the ${ }^{1} \mathrm{H}$ NMR spectra of all samples (see Supplementary Materials), there was no signal of the hydrogen of the carboxyl group in the region of $\sim 11.5 \mathrm{ppm}$ [29], indicating the absence of residual acids in the obtained substances. On the spectrum of $\left[\mathrm{Zr}(\mathrm{Ac})_{\mathrm{x}}\right]$, the hydrogen signal of the methyl group split to a multiplet. For all samples, a shift of the hydrogen signals to the high-field region is observed; this effect is more pronounced for hydrogen of methyl/methylenes adjacent to the $\mathrm{COO}^{-}$ group. The splitting and shifting of hydrogen signals indicate the coordination of carboxylate moieties to the metal, as well as the formation of metal carboxylate associates. A similar signal shifting is observed for other carboxylates (e.g., lithium acetate, sodium octanoate) [29].

On the $\left.{ }^{13} \mathrm{C}_{\{}{ }^{1} \mathrm{H}\right\}$ NMR spectrum of $\left[\mathrm{Zr}(\mathrm{Ac})_{\mathrm{x}}\right]$, for carbon signals of $\mathrm{COO}^{-}$and $\mathrm{CH}_{3}$-groups, splitting and a shift to lower fields are observed. According to the Spectral Database for Organic Compounds [29], the carbon signal of $\mathrm{COO}^{-}$group in acetic acid is observed at $178.1 \mathrm{ppm}$. On the spectrum of the $\left[\mathrm{Zr}(\mathrm{Ac})_{\mathrm{x}}\right]$, the carbon signals of the $\mathrm{COO}^{-}$group are presented as a triplet at $177.7-177.9 \mathrm{ppm}$ and singlets at $176.5 \mathrm{ppm}$ and $181.2 \mathrm{ppm}$. The signal of the acetic acid $\mathrm{CH}_{3}$-group is observed at $20.8 \mathrm{ppm}$ [29], while in the case of $\left[\mathrm{Zr}(\mathrm{Ac})_{\mathrm{x}}\right]$, it splits into a quadruplet at $23.6-24.1 \mathrm{ppm}$, a singlet at $23.1 \mathrm{ppm}$ and a shoulder at $21.0 \mathrm{ppm}$. Similar effects were observed for the carboxylate group and the methyl group adjacent to it in the case of $\left[\mathrm{Zr}(\mathrm{Oct})_{\mathrm{X}}\right]$ and $\left[\mathrm{Zr}(\operatorname{Laur})_{\mathrm{X}}\right]$ (see Supplementary Materials).

The relative intensity of the $\mathrm{COO}^{-}$group carbon signal is reduced compared to the $\mathrm{CH}_{3} / \mathrm{CH}_{2}$ groups carbon signals (in the case of $\left[\mathrm{Zr}(\operatorname{Laur})_{\mathrm{x}}\right]$, the signal at $\sim 180 \mathrm{ppm}$ is not observed, probably due to its limited solubility in $\mathrm{CDCl}_{3}$ ).

The splitting and shifting of carbon signals of $\mathrm{COO}^{-}, \mathrm{CH}_{3}-\left(\right.$ for $\left.\left[\mathrm{Zr}(\mathrm{Ac})_{\mathrm{x}}\right]\right)$ and $-\alpha \mathrm{CH}_{2}$-groups $\left(\right.$ for $\left[\mathrm{Zr}(\mathrm{Oct})_{\mathrm{x}}\right]$ and $\left.\left[\mathrm{Zr}(\operatorname{Laur})_{\mathrm{x}}\right]\right)$, as well as the decrease in their intensity, are due to a change in the electron density at these carbon atoms as a result of the coordination of carboxylate moieties to zirconium [30-32]. Also, conformational changes in carboxylate moieties and the formation of their nonequivalence due to different interactions with the metal center may be the cause of the observed splitting and shift of the carbon signals [33,34]. A similar effect of the splitting of carbon signals of the $\mathrm{COO}^{-}$and $-\alpha \mathrm{CH}_{2}$-groups is observed for lead(II) carboxylates [35]. The shift of the $\mathrm{COO}^{-}$group carbon signal to lower fields is also observed for carboxylates of other metals [29].

\subsection{IR Spectroscopy}

Electrochemical products were investigated by IR spectroscopy (Figure 3). 


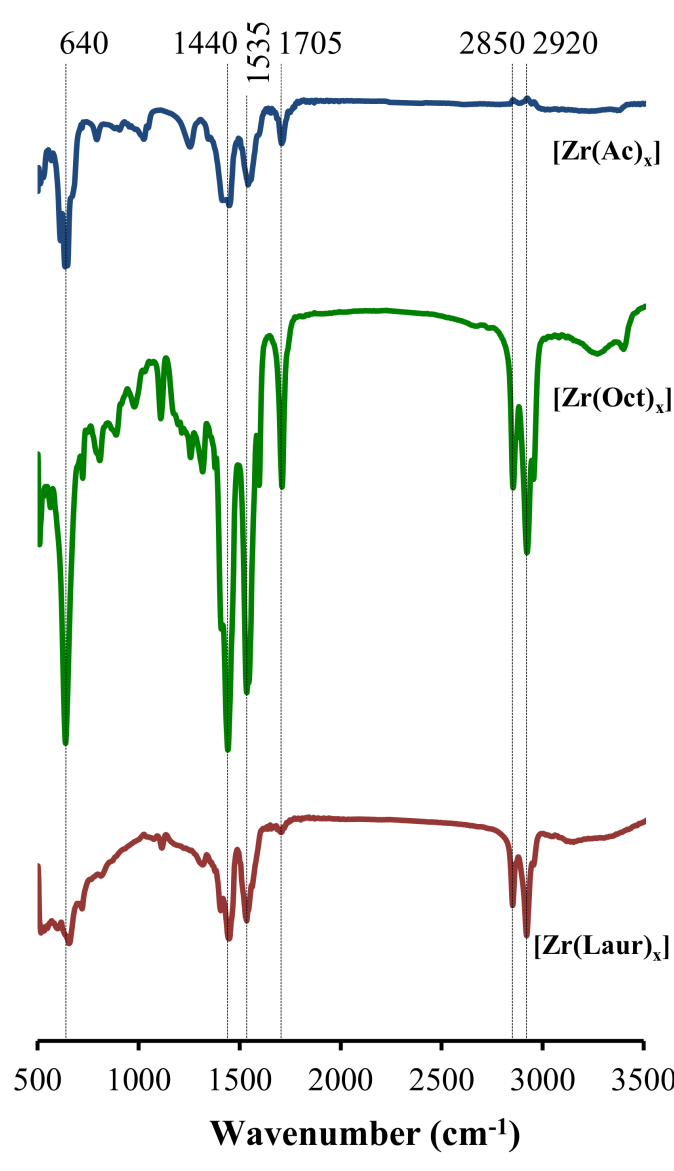

(a)
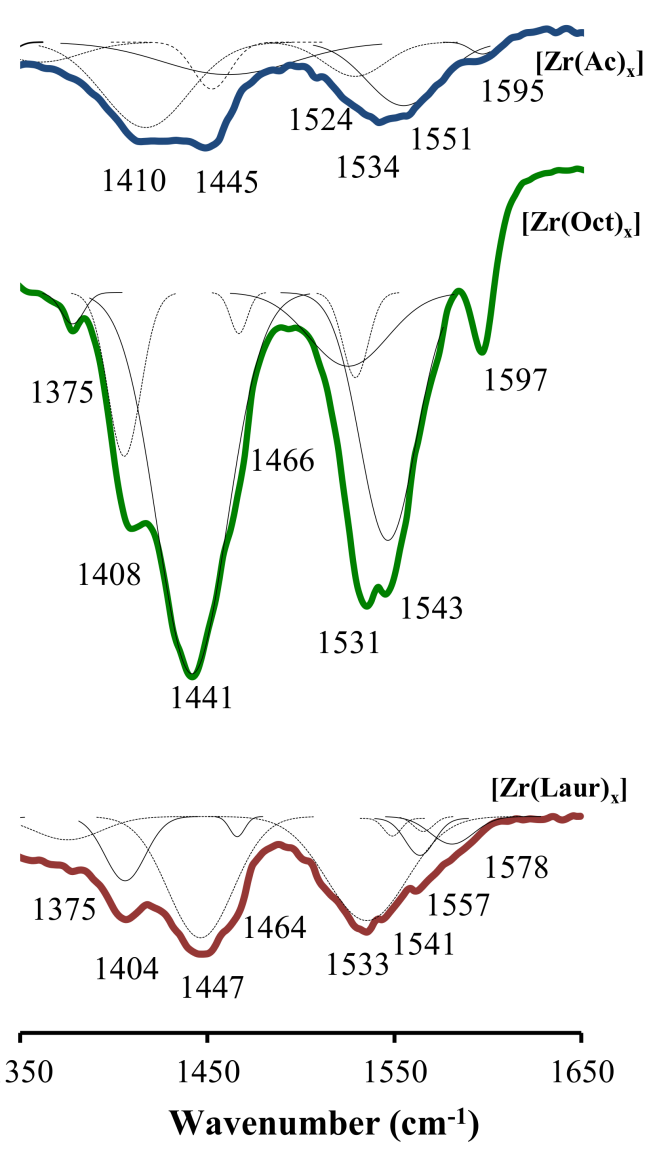

(b)

Figure 3. (a) Infrared (IR)-spectra of electrosynthesized $\left[\mathrm{Zr}(\mathrm{Ac})_{\mathrm{x}}\right],\left[\mathrm{Zr}(\mathrm{Oct})_{\mathrm{x}}\right],\left[\mathrm{Zr}(\mathrm{Laur})_{\mathrm{x}}\right]$; (b) $1350-1650 \mathrm{~cm}^{-1}$ region of IR spectra.

The IR spectra of the samples have signals in the region of $\sim 2900 \mathrm{~cm}^{-1}$ corresponding to stretching vibrations of the $\mathrm{CH}_{2}$ - and $\mathrm{CH}_{3}$-groups [36]. Signals at $\sim 640, \sim 1440, \sim 1530 \mathrm{~cm}^{-1}$ are characteristic of the formation of metal carboxylates. Absorption at $\sim 640 \mathrm{~cm}^{-1}$ corresponds to the $\mathrm{COO}^{-}$group bending mode [37]. As a result of the formation of zirconium carboxylates, the absorption band at $\sim 1700 \mathrm{~cm}^{-1}$, which is assigned to antisymmetric stretching vibrations of the $\mathrm{C}=\mathrm{O}$ bond in hydrogen-bonded dimers [38], is converted into signals of symmetric $\left(v_{\text {sym }}\left(\mathrm{COO}^{-}\right)\right.$at $\left.1390-1460 \mathrm{~cm}^{-1}\right)$ and asymmetric $\left(v_{\text {asym }}\left(\mathrm{COO}^{-}\right)\right.$at $\left.1520-1590 \mathrm{~cm}^{-1}\right)$ stretching vibrations of the carboxylate group [29,36,39] (Figure 3 and Supplementary Materials).

The ratio of intensities and the position of the signals $v_{\mathrm{asym}}\left(\mathrm{COO}^{-}\right)$and $v_{\mathrm{sym}}\left(\mathrm{COO}^{-}\right)$in the IR spectrum, as well as the difference of their frequencies $\Delta v$, are widely used to characterize the coordination mode of the carboxylate group to the metal [40,41]. For the studied samples, close intensities of $v_{\mathrm{sym}}\left(\mathrm{COO}^{-}\right)$and $v_{\mathrm{asym}}\left(\mathrm{COO}^{-}\right)$signals indicate the equivalence of $\mathrm{C}-\mathrm{O}$ bonds in the carboxylate group [41,42]. The $v_{\text {asym }}\left(\mathrm{COO}^{-}\right)$signals have frequencies of $1530-1540 \mathrm{~cm}^{-1}$, which are lower than corresponding signals for the ionic and monodentate coordinated carboxylates (1600-1630 $\mathrm{cm}^{-1}$ ) [40]. In addition, the frequency difference of $\Delta v=86-106 \mathrm{~cm}^{-1}$ (Figure 3) is significantly lower than the difference for the monodentate coordinated carboxylate $(\Delta v=$ 230-300 $\left.\mathrm{cm}^{-1}\right)[40,41]$ and corresponds to those for the chelate bidentate and bridge bidentate coordination $[40,41,43]$. Therefore, in the electrochemically synthesized $\left[\mathrm{Zr}(\mathrm{Ac})_{\mathrm{x}}\right],\left[\mathrm{Zr}(\mathrm{Oct})_{\mathrm{x}}\right]$ and $\left[\mathrm{Zr}(\operatorname{Laur})_{\mathrm{x}}\right]$, both bidentate bridging and chelating coordination of $\mathrm{COO}^{-}$groups to zirconium could be observed. The Gauss decomposition of IR spectra (Figure 3b) confirms the variety of bidentate 
$\left(\Delta v=86-158 \mathrm{~cm}^{-1}\right)$ coordination modes of carboxylate moieties to zirconium. The lack of order in the coordination of carboxylate moieties to the metal center may be the reason of non-stoichiometric zirconium carboxylate formation $[18,28]$.

As a result of the zirconium carboxylate formation, the signal at $920-940 \mathrm{~cm}^{-1}$ (assigned to a $\mathrm{C}-\mathrm{C}$ stretch adjacent to $\mathrm{COO}^{-}$) disappeared and the intensity of the $\mathrm{CH}_{2}$ rocking vibration signal at $720 \mathrm{~cm}^{-1}$ decreased (see Supplementary Materials) [37,43]. This is consistent with the results of ${ }^{13} \mathrm{C}\left\{{ }^{1} \mathrm{H}\right\}$ NMR spectroscopy: a decrease in the intensity of signals of carbon atoms adjacent to the carboxylate group (see Supplementary Materials).

\subsection{Powder X-Ray Diffraction (PXRD)}

Solid products of electrosynthesis (based on acetic and lauric acids) were studied by PXRD. A high level of background in the diffractograms (Figure 4) indicates that the products of electrosynthesis are amorphous substances. At the same time, they contain an ordered mesophase, which causes an intense reflection in the region of small angles $\left(3.4-7.7^{\circ}\right)$. With an increase in the number of carbon atoms in the carboxylate from 2 to 12 (with the transition from $\left[\mathrm{Zr}(\mathrm{Ac})_{\mathrm{x}}\right]$ to $\left[\mathrm{Zr}(\operatorname{Laur})_{\mathrm{x}}\right]$ ), the $\mathrm{d}$ Bragg spacing value corresponding to this reflection increases from $11.5 \AA\left(2 \theta=7.7^{\circ}\right)$ to $26.0 \AA\left(2 \theta=3.4^{\circ}\right)$. A similar effect was observed in the work [42] for cerium(III) carboxylates.

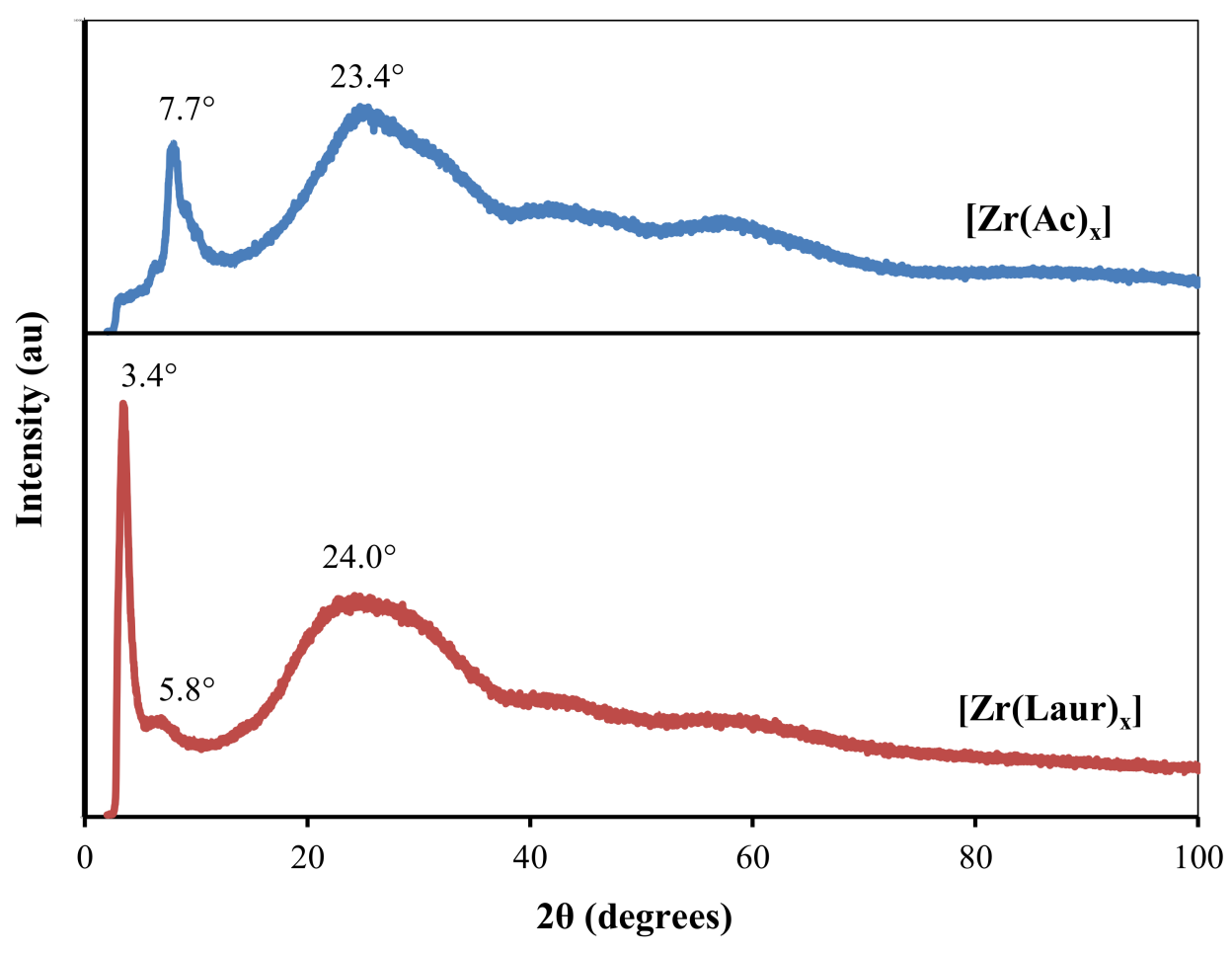

Figure 4. Powder X-ray diffractograms for $\left[\mathrm{Zr}(\mathrm{Ac})_{\mathrm{x}}\right]$ and $\left[\mathrm{Zr}(\operatorname{Laur})_{\mathrm{x}}\right]$ (at room temperature).

The ratio of $\mathrm{d}$ Bragg spacing values corresponding to neighboring reflections in the diffractogram of $\left[\mathrm{Zr}(\operatorname{Laur})_{\mathrm{x}}\right]\left(\right.$ at $2 \theta=3.4^{\circ}$ and $\left.2 \theta=5.8^{\circ}\right)$ is $1: \sqrt{ } 3$. This indicates the hexagonal packing of the mesophase. In addition, the $\mathrm{d}$ Bragg spacing value of $26.0 \AA$, which corresponds to the main reflection at $2 \theta=$ $3.4^{\circ}$, is more characteristic of the hexagonal packing than of the lamellar structure (typical for most carboxylates) with the same length of the alkyl chain [37,42,43].

In the range $2 \theta=20-40^{\circ}$, a wide halo is observed, which corresponds to diffraction from disordered alkyl chains $[37,44]$. 


\subsection{Ethylene Oligomerization}

Electrochemically synthesized $\left[\operatorname{Zr}(\mathrm{Ac})_{\mathrm{x}}\right],\left[\mathrm{Zr}(\mathrm{Oct})_{\mathrm{x}}\right]$ and $\left[\operatorname{Zr}(\operatorname{Laur})_{\mathrm{x}}\right](3<\mathrm{x}<4)$ were used as pre-catalysts in ethylene oligomerization. The results of the catalytic tests are shown in Table 3. The product of oligomerization is the mixture of even-numbered olefins, predominantly LAOs, with a wide distribution on the carbon atoms, following Schulz-Flory law $[45,46]$. For the characterization of oligomer distribution on molecular weight, a Schulz-Flory parameter " $\alpha$ " was used, which is equal to the ratio of the propagation rate to the sum of propagation and chain transfer rates [45]. Consequently, on the basis of the Schulz-Flory parameter, the molecular weight distribution of oligomers was calculated (Table 3) $[45,46]$. In addition, in all oligomerization products, there were alkylbenzenes (mainly products of solvent (toluene) alkylation by $\mathrm{C}_{4}-\mathrm{C}_{8}$-olefins) in an amount of $0.3-1.3 \mathrm{wt} \%$.

Table 3. Results of catalytic ethylene oligomerization tests. ${ }^{1}$

\begin{tabular}{|c|c|c|c|c|c|c|c|c|c|c|c|}
\hline & \multirow[b]{2}{*}{ Pre-Catalyst } & \multirow[b]{2}{*}{ Activator } & \multirow[b]{2}{*}{$\mathrm{Al} / \mathrm{Zr}$} & \multirow{2}{*}{$\begin{array}{l}\mathrm{T}^{2} \\
\left({ }^{\circ} \mathrm{C}\right)\end{array}$} & \multirow[b]{2}{*}{$\alpha^{3}$} & \multicolumn{4}{|c|}{ Oligomer Distribution, wt $\%$} & \multirow{2}{*}{$\begin{array}{c}S(\alpha=)^{4} \\
(\%)\end{array}$} & \multirow{2}{*}{$\begin{array}{c}A^{5} \times \\
10^{3}\end{array}$} \\
\hline & & & & & & $\mathrm{C}_{4}-\mathrm{C}_{10}$ & $\mathrm{C}_{12}-\mathrm{C}_{20}$ & $\mathrm{C}_{20}-\mathrm{C}_{30}$ & $\begin{array}{c}\mathrm{C}_{30+} \\
\text { (+polymer) }\end{array}$ & & \\
\hline 1 & $\mathrm{ZrCl}_{4}$ & $\mathrm{Et}_{2} \mathrm{AlCl}$ & 20 & 80 & 0.40 & 92.8 & 6.3 & 0.1 & 0.8 & 83 & 6.0 \\
\hline $2^{6}$ & {$\left[\mathrm{Zr}(\mathrm{Ac})_{\mathrm{y}}\right]^{\text {chem }}$} & $\mathrm{Et}_{3} \mathrm{Al}_{2} \mathrm{Cl}_{3}$ & 20 & 80 & 0.44 & 91.1 & 8.6 & 0.2 & 0.1 & 80 & 7.1 \\
\hline 3 & {$\left[\mathrm{Zr}(\mathrm{Ac})_{\mathrm{x}}\right]$} & $\mathrm{Et}_{3} \mathrm{Al}_{2} \mathrm{Cl}_{3}$ & 20 & 80 & 0.46 & 89.0 & 10.3 & 0.4 & 0.3 & 78 & 7.6 \\
\hline 4 & {$\left[\mathrm{Zr}(\mathrm{Oct})_{\mathrm{x}}\right]$} & $\mathrm{Et}_{3} \mathrm{Al}_{2} \mathrm{Cl}_{3}$ & 20 & 80 & 0.52 & 82.7 & 15.9 & 1.1 & 0.3 & 85 & 9.9 \\
\hline 5 & {$\left[\mathrm{Zr}(\mathrm{Laur})_{\mathrm{X}}\right]$} & $\mathrm{Et}_{3} \mathrm{Al}_{2} \mathrm{Cl}_{3}$ & 20 & 80 & 0.60 & 71.8 & 24.4 & 3.3 & 0.5 & 85 & 9.5 \\
\hline 6 & {$\left[\mathrm{Zr}(\mathrm{Oct})_{\mathrm{x}}\right]$} & $\mathrm{EtAlCl}_{2}$ & 20 & 80 & & 86.5 & \multicolumn{2}{|c|}{ alkylbenzenes $=13.4$} & 0.1 & n.d. ${ }^{7}$ & 1.7 \\
\hline 7 & {$\left[\mathrm{Zr}(\mathrm{Oct})_{\mathrm{x}}\right]$} & $\mathrm{Et}_{2} \mathrm{AlCl}$ & 20 & 80 & 0.56 & 77.9 & 19.4 & 1.8 & 0.9 & 81 & 7.1 \\
\hline 8 & {$\left[\mathrm{Zr}(\mathrm{Oct})_{\mathrm{x}}\right]$} & $\mathrm{AlEt}_{3}$ & 20 & 80 & & \multicolumn{3}{|c|}{$\mathrm{C}_{4}-\mathrm{C}_{26}=5.3$} & 94.7 & n.d. ${ }^{7}$ & 1.3 \\
\hline 9 & {$\left[\mathrm{Zr}(\mathrm{Oct})_{\mathrm{x}}\right]$} & $\mathrm{Et}_{3} \mathrm{Al}_{2} \mathrm{Cl}_{3}$ & 20 & 60 & 0.57 & 76.5 & 20.9 & 2.2 & 0.5 & 91 & 6.7 \\
\hline 10 & {$\left[\mathrm{Zr}(\mathrm{Oct})_{\mathrm{x}}\right]$} & $\mathrm{Et}_{3} \mathrm{Al}_{2} \mathrm{Cl}_{3}$ & 20 & 100 & 0.48 & 87.1 & 12.0 & 0.5 & 0.4 & 75 & 13.6 \\
\hline $11^{8}$ & {$\left[\mathrm{Zr}(\mathrm{Oct})_{\mathrm{x}}\right]$} & $\mathrm{Et}_{3} \mathrm{Al}_{2} \mathrm{Cl}_{3}$ & 20 & 80 & 0.60 & 72.3 & 24.1 & 3.2 & 0.4 & 86 & 14.0 \\
\hline 12 & {$\left[\mathrm{Zr}(\mathrm{Oct})_{\mathrm{x}}\right]$} & $\mathrm{Et}_{3} \mathrm{Al}_{2} \mathrm{Cl}_{3}$ & 10 & 80 & 0.76 & 40.5 & 36.0 & 15.4 & 8.1 & 97 & 8.3 \\
\hline 13 & {$\left[\mathrm{Zr}(\mathrm{Oct})_{\mathrm{x}}\right]$} & $\mathrm{Et}_{3} \mathrm{Al}_{2} \mathrm{Cl}_{3}$ & 40 & 80 & 0.45 & 90.2 & 9.5 & 0.3 & 0 & 83 & 7.6 \\
\hline $14^{9}$ & {$\left[\mathrm{Zr}(\mathrm{Oct})_{\mathrm{x}}\right]$} & $\mathrm{Et}_{3} \mathrm{Al}_{2} \mathrm{Cl}_{3}$ & 20 & 80 & 0.52 & 83.6 & 15.4 & 0.9 & 0.1 & 97 & 31.3 \\
\hline
\end{tabular}

${ }^{1}$ Reaction conditions: amount of pre-catalyst, $40 \mu \mathrm{mol}$; solvent, toluene $(25 \mathrm{~mL})$; ethylene pressure, 20 bar; reaction time, 60 min. ${ }^{2} \mathrm{~T}$, thermostat temperature. ${ }^{3} \alpha$, Schulz-Flory parameter. ${ }^{4} S(\alpha)$, selectivity to linear alpha-olefins, calculated as the average for $\mathrm{C}_{10}, \mathrm{C}_{12}, \mathrm{C}_{14}$ and $\mathrm{C}_{16}$ fractions. ${ }^{5}$ Activity $[\mathrm{A}]=\left[\mathrm{mol}_{\mathrm{C} 2 \mathrm{H} 4} \cdot \mathrm{mol}_{\mathrm{Zr}}{ }^{-1} \cdot \mathrm{h}^{-1}\right]$, (mol of ethylene converted $) \times(\mathrm{mol} \text { of } \mathrm{Zr})^{-1} \times \mathrm{h}^{-1} .{ }^{6}\left[\mathrm{Zr}(\mathrm{Ac})_{\mathrm{y}}\right]^{\text {chem }}$ is the chemically synthesized zirconium acetate. ${ }^{7} \mathrm{~N} . d .$, not determined. ${ }^{8}$ Ethylene pressure was 30 bar. ${ }^{9}$ Reaction conditions: amount of pre-catalyst, $20 \mu$ mol; ethylene pressure, 30 bar; reaction time, $30 \mathrm{~min}$.

Zirconium acetates obtained by chemical and electrochemical methods have similar catalytic properties in ethylene oligomerization (entries 2 and 3, Table 3). With the increasing length of the carboxylate moiety, the distribution of oligomers shifts to the higher molecular weights. This is indicated by the increase of the Schulz-Flory parameter from 0.46 (for acetate) to 0.52 (for octanoate) and 0.60 (for laurate) (entries 3-5, Table 3, Figure 5a). At the same time, the activity of the catalytic system increased from $7.6 \times 10^{3}$ to $9.9 \times 10^{3}$ and $9.5 \times 10^{3} \mathrm{~mol}_{\mathrm{C} 2 \mathrm{H} 4} \cdot \mathrm{mol}_{\mathrm{Zr}}{ }^{-1} \cdot \mathrm{h}^{-1}$, respectively. The formation of longer chain oligomers may indicate the existence of a certain similarity between the length of the alkyl chain in $\mathrm{Zr}-\mathrm{R}$ catalytic intermediate and the length of the carboxylate moiety in the initial pre-catalyst. The increase in activity upon transition from $\left[\operatorname{Zr}(\mathrm{Ac})_{X}\right]$ to $\left[\operatorname{Zr}(\mathrm{Oct})_{X}\right]$ and $\left[\operatorname{Zr}(\operatorname{Laur})_{X}\right]$ may be due to the increase of their solubility in toluene [47]. The electrochemically synthesized zirconium carboxylates are superior in activity to $\mathrm{ZrCl}_{4}$ and provide the formation of a smaller amount of polymer (entries 1 and 3-5, Table 3).

Using $\left[\mathrm{Zr}(\mathrm{Oct})_{\mathrm{x}}\right]$, the effects of nature and the amount of co-catalyst $(\mathrm{Al} / \mathrm{Zr}$ ratio), as well as of process parameters (temperature, pressure), on catalytic properties were investigated.

The decrease of thermostat temperature from $80^{\circ} \mathrm{C}$ to $60^{\circ} \mathrm{C}$ led to the decrease of activity from 9.9 $\times 10^{3}$ to $6.7 \times 10^{3} \mathrm{~mol}_{\mathrm{C} 2 \mathrm{H} 4} \cdot \mathrm{mol}_{\mathrm{Zr}}^{-1} \cdot \mathrm{h}^{-1}$ and to the increase of the selectivity to LAO (entry 9, Table 3). The latter is probably due to a decrease in the rate of isomerization. At the same time, the length of the oligomers formed increased; $\alpha$ increased from 0.52 to 0.57 due to the decrease of chain transfer rate with temperature [48-50]. Therefore, chain transfer and chain isomerization have higher activation energies than chain propagation. With the increasing of oligomerization temperature to $100^{\circ} \mathrm{C}$, opposite effects 
were observed-the activity increased to $13.6 \times 10^{3} \mathrm{~mol}_{\mathrm{C} 2 \mathrm{H} 4} \cdot \mathrm{mol}_{\mathrm{Zr}}{ }^{-1} \cdot \mathrm{h}^{-1}, \alpha$ decreased to 0.48 and selectivity to LAO decreased to $75 \%$ (entry 10 , Table 3 ).

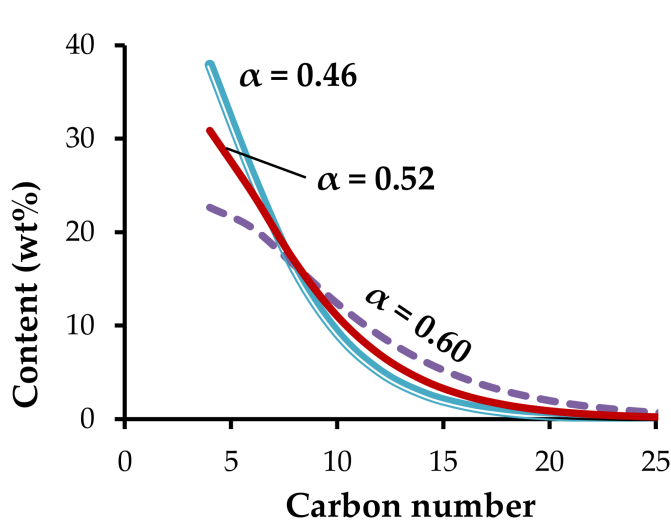

(a)

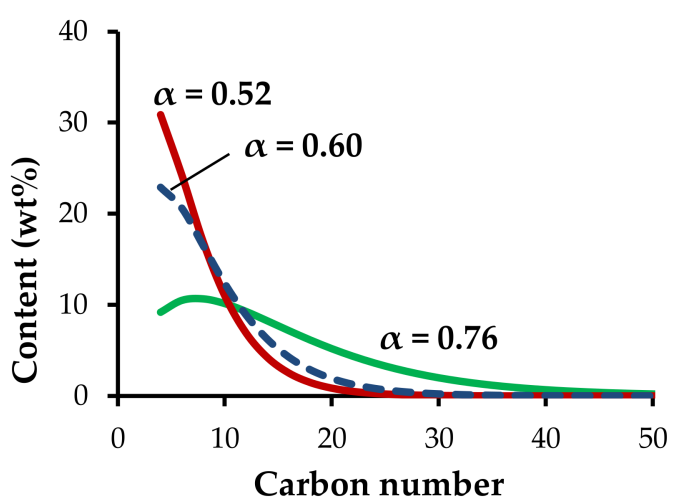

(b)

Figure 5. Distribution of olefins in the products of ethylene oligomerization using, as a pre-catalyst, (a) $\left[\mathrm{Zr}(\mathrm{Ac})_{\mathrm{X}}\right](\alpha=0.46),\left[\mathrm{Zr}(\mathrm{Oct})_{\mathrm{X}}\right](\alpha=0.52)$ and $\left[\mathrm{Zr}(\mathrm{Laur})_{\mathrm{X}}\right](\alpha=0.60) ;(\mathbf{b})\left[\mathrm{Zr}(\mathrm{Oct})_{\mathrm{x}}\right], 20 \mathrm{bar}-\mathrm{Al} / \mathrm{Zr}=$ $20(\alpha=0.52) ; 30$ bar-Al/Zr $=20(\alpha=0.60) ; 20$ bar $-\mathrm{Al} / \mathrm{Zr}=10(\alpha=0.76), \mathrm{T}=80^{\circ} \mathrm{C}$.

The increase of the ethylene pressure to 30 bar resulted in an increase of productivity to $14.0 \times$ $10^{3} \mathrm{~mol}_{\mathrm{C} 2 \mathrm{H} 4} \cdot \mathrm{mol}_{\mathrm{Zr}}{ }^{-1} \cdot \mathrm{h}^{-1}$ (entry 11 , Table 3 ). At the same time, the molecular weight of oligomers increased (as indicated by the growth of $\alpha$ to 0.60 ), probably due to the intensification of the ethylene insertion to the $\mathrm{Zr}-\mathrm{C}$ bond at the chain propagation stage of the catalytic cycle [50].

The characteristics of oligomerization products are strongly dependent on the nature and the amount of co-catalyst used. A decrease in the acidity of aluminum in the co-catalyst causes an increase in the amount of polymer formed. For example, in the transition from $\mathrm{Et}_{3} \mathrm{Al}_{2} \mathrm{Cl}_{3}$ to $\mathrm{Et}_{2} \mathrm{AlCl}$, the polymer content increased from 0.3 to $0.9 \mathrm{wt} \%$ (entry 7, Table 3). In the case of $\mathrm{AlEt}_{3}$ as a co-catalyst, predominant polymerization was observed (entry 8, Table 3). In turn, in the presence of the co-catalyst with higher aluminum acidity-Et $\mathrm{AlCl}_{2}$-along with oligomerization, toluene alkylation could take place (entry 6, Table 3).

The decrease of the $\mathrm{Al} / \mathrm{Zr}$ ratio from 20 to 10 led to a decrease in activity and to a significant increase in the chain length of oligomers (entry 12, Table 3; Figure 5b). At the same time, selectivity to LAO increased to $97 \%$ as a result of the decrease in the number of aluminum acid centers which are active in olefin isomerization [51,52]. In turn, the increase of the $\mathrm{Al} / \mathrm{Zr}$ ratio from 20 to 40 resulted in the shortening of oligomers ( $\alpha$ decreased to 0.45 ) and decrease in activity to $7.6 \times 10^{3} \mathrm{~mol}_{\mathrm{C} 2 \mathrm{H} 4} \cdot \mathrm{mol}_{\mathrm{Zr}}{ }^{-1} \cdot \mathrm{h}^{-1}$ (entry 13, Table 3). An increase in the content of short-chain oligomers, which resulted from the increase in the $\mathrm{Al} / \mathrm{Zr}$ ratio, is consistent with ethylene oligomerization kinetic studies using the $\mathrm{Zr}\left(\mathrm{OC}_{3} \mathrm{H}_{7}\right)_{4}-\mathrm{Et}_{3} \mathrm{Al}_{2} \mathrm{Cl}_{3}$ system [53].

A twofold decrease in the amount of pre-catalyst and reaction time, as well as an increase in ethylene pressure to $30 \mathrm{bar}$, led to an increase in the activity to $31.3 \times 10^{3} \mathrm{~mol}_{\mathrm{C} 2 \mathrm{H} 4} \cdot \mathrm{mol}_{\mathrm{Zr}}{ }^{-1} \cdot \mathrm{h}^{-1}$ (entry 14 , Table 3).

Thus, electrochemically synthesized zirconium carboxylates, in combination with $\mathrm{Et}_{3} \mathrm{Al}_{2} \mathrm{Cl}_{3}$, oligomerize ethylene with moderate activity $\left(7.6 \times 10^{3}-9.9 \times 10^{3} \mathrm{~mol}_{\mathrm{C} 2 \mathrm{H} 4} \cdot \mathrm{mol}_{\mathrm{Zr}}{ }^{-1} \cdot \mathrm{h}^{-1}\right)$ to even-numbered linear alpha-olefins (78-85\%) with Schulz-Flory distribution, predominantly to $\mathrm{C}_{4}-\mathrm{C}_{10}$ olefins (72-89\%). The performance of catalytic systems investigated is in accordance with the literature data on ethylene oligomerization using zirconium carboxylates $[16,17,54-56]$. 


\section{Materials and Methods}

In electrosynthesis processes, a power source AKIP-1137-200-1 (AKIP, Russia) was used. Commercial acetonitrile (analytical grade, EKOS-1, Russia), zirconium(IV) chloride (98\%, anhydrous, ACROS Organics), acetic acid (reagent grade, EKOS-1, Russia), octanoic acid (99\%; ACROS Organics), lauric (dodecanoic) acid (99\%; ACROS Organics), tetraethylammonium chloride $\mathrm{Et}_{4} \mathrm{NCl}(\geq 98 \%$; Sigma-Aldrich, St. Louis, Missouri, USA) and tetra-n-butylammonium tetrafluoroborate ${ }^{\mathrm{n}} \mathrm{Bu}_{4} \mathrm{NBF}_{4}$ (99\%; Alfa Aesar) were used as received without further purification.

Metal zirconium, obtained by iodide technology (99.8 wt\%; Chepetsk Mechanical Plant, Russia), was used for the anode and cathode (plates, $S=510 \mathrm{~mm}^{2}$ ) during the electrosynthesis procedures.

Voltammetric studies were performed using an EC Epsilon potentiostat with a C3 module (BASi, West Lafayette, IN, USA). Metal zirconium was used as the working electrode (plate, $S=90 \mathrm{~mm}^{2}$ ), a platinum wire was used as the auxiliary electrode and $\mathrm{Ag} / \mathrm{Ag}^{+}\left(0.01 \mathrm{~mol} \cdot \mathrm{L}^{-1} \mathrm{AgNO}_{3}\right.$ in acetonitrile, $\left(\mathrm{E}^{\circ}\left(\mathrm{Fc} / \mathrm{Fc}^{+}\right)=+0.20 \mathrm{~V}\right)$ served as the reference electrode. All curves were recorded at a potential sweep rate of $100 \mathrm{mV} \times \mathrm{s}^{-1}$.

The content of the zirconium in the products of electrochemical synthesis was determined by the burning of the sample at $1000{ }^{\circ} \mathrm{C}$ in an oxygen flow followed by weighing the residue $\left(\mathrm{ZrO}_{2}\right)$. The residue mass was converted to metal.

Carbon and hydrogen content was determined using the high-temperature single-reactor analyzer CHN-3 (Chimavtomatika, Russia) by burning the sample at $950{ }^{\circ} \mathrm{C}$ in an oxygen flow and the chromatographic determination of oxidation products $\left(\mathrm{CO}_{2}\right.$ and $\left.\mathrm{H}_{2} \mathrm{O}\right)$.

The content of chlorine was determined by the Sheniger procedure [57].

NMR spectra were collected at room temperature using an Avance III $400 \mathrm{MHz}$ spectrometer (Bruker, Germany) operating at $400 \mathrm{MHz}\left({ }^{1} \mathrm{H}\right)$ and $100.6 \mathrm{MHz}\left({ }^{13} \mathrm{C}\right)$. Typically, 10,000-30,000 scans were collected with a sweep width of $24038 \mathrm{~Hz}(238.869 \mathrm{ppm})$ and relaxation delay of $0.63 \mathrm{~s}$.

IR spectra were recorded using an FT-801 FT-IR spectrometer (SIMEX, Russia) and an NPVO-ZDO single-reflectance ATR accessory (SIMEX, Russia) with ZnSe crystal. Spectra were recorded over the range $4000-500 \mathrm{~cm}^{-1}$, with a resolution of $2 \mathrm{~cm}^{-1}$ and averaged over 64 scans. To obtain good contact with ATR crystal the samples were clamped by a swivel tip press.

Powder X-ray diffraction (PXRD) measurements were carried out using a MiniFlex 600 diffractometer (Rigaku, Japan). The patterns were collected using $\mathrm{CuK} \alpha$ radiation $(40 \mathrm{kV}, 15 \mathrm{~mA})$ at room temperature in the range of $2 \theta$ from 2 to $100^{\circ}$ with $0.02^{\circ}$ steps and a $0.24 \mathrm{~s}$ exposure time at each point.

GC-MS analyses were performed on a GC 7890-MSD 5977B system (Agilent, USA) equipped with capillary column HP-5MS Ultra Inert $(30 \mathrm{~m}$ length, $0.25 \mathrm{~mm}$ diameter, $0.50 \mu \mathrm{m}$ film of (5\%-phenyl)-methylpolysiloxane; Agilent, USA). For chromatography, the following temperature program was used-thermostating at $35^{\circ} \mathrm{C}$ for $10 \mathrm{~min}$; heating to $120^{\circ} \mathrm{C}$ with a rate of $\left(10^{\circ} \times \mathrm{min}^{-1}\right)$, thermostating at $120^{\circ} \mathrm{C}$ for $3 \mathrm{~min}$; and heating to $280^{\circ} \mathrm{C}$ with a rate of $\left(20^{\circ} \times \mathrm{min}^{-1}\right)$ and thermostating at $280{ }^{\circ} \mathrm{C}$ for $10 \mathrm{~min}$. Substances were identified using the NIST Mass Spectral Search Program (National Institute of Standards and Technology, USA), version 2.2.

\subsection{Cyclic Voltammetry}

In cyclic voltammetric studies, flat metal zirconium with a surface of $90 \mathrm{~mm}^{2}$ was used as a working electrode, a silver electrode $\mathrm{Ag} / \mathrm{AgNO}_{3}\left(0.01 \mathrm{~mol} \cdot \mathrm{L}^{-1}\right.$ solution in acetonitrile $)$ was used as a reference electrode and a platinum wire served as an auxiliary electrode. The electrolyte was a solution of a carboxylic acid and a supporting salt $\left(0.01 \mathrm{~mol} \cdot \mathrm{L}^{-1}\right)$ in acetonitrile $(5 \mathrm{~mL})$. Voltammograms were recorded according to the following order of voltage change-from 0 to $-2.0 \mathrm{~V}$, from -2.0 to $2.0 \mathrm{~V}$ and from 2.0 to $0 \mathrm{~V}$. For each system, three continuous scanning cycles were performed; the third cycles are shown in Figures 1 and 2 and in Supplementary Materials. 


\subsection{Preparative Electrolysis}

The electrochemical synthesis was carried out in an electrochemical cell without separation of the anodic and cathodic compartments. A working solution for electrolysis was prepared by dissolving the supporting salt $\left(1 \times 10^{-4} \mathrm{~mol}\right)$ and the corresponding carboxylic acid in acetonitrile $(10 \mathrm{~mL})$. A flat zirconium anode with a working surface area of $510 \mathrm{~mm}^{2}$ and an identical zirconium cathode were used. The electrolysis was carried out in a potentiostatic mode, without stirring and thermostating of the electrolyte. The process was completed when the current decreased to $10 \mathrm{~mA}$ as a result of partially coating the anode surface by product. To calculate the current efficiency, the amount of transmitted electricity was integrated.

\subsubsection{Electrosynthesis of $\left[\mathrm{Zr}(\mathrm{Ac})_{\mathrm{x}}\right]$}

In total, $16 \mathrm{mg}\left(1 \times 10^{-4} \mathrm{~mol}\right)$ of $\mathrm{Et}_{4} \mathrm{NCl}$ and $2.0 \mathrm{~mL}\left(35 \times 10^{-3} \mathrm{~mol}\right)$ of acetic acid were dissolved in $10 \mathrm{~mL}$ of acetonitrile. Zirconium electrodes were immersed in the electrolyte. To prevent short circuits, the electrodes were separated by a PTFE plate.

Electrolysis was carried out at a constant voltage of $80 \mathrm{~V}$. The current was stable at $\sim 50 \mathrm{~mA}$. During the initial $45 \mathrm{~min}$ of electrolysis, the solution temperature increased to $60{ }^{\circ} \mathrm{C}$ and was kept constant. After 110 min of electrolysis, the precipitation of white solid started, which led to a decrease in current. The total electrolysis time was $160 \mathrm{~min}$. The working solution was left for $120 \mathrm{~min}$, during which an additional amount of the product was precipitated from the solution. Then, the electrolyte was poured out of the cell. The resulting precipitate was washed three times with $10 \mathrm{~mL}$ of fresh acetonitrile and subsequently dissolved in $30 \mathrm{~mL}$ of acetone. The resulting solution was filtered from metal particles (scree from anode) using a PTFE filter with a pore size of $0.45 \mu \mathrm{m}$ (MACHEREY-NAGEL, Germany). Acetone was removed and the product was dried under reduced pressure and $80^{\circ} \mathrm{C}$. The product was obtained as white flakes. The yield was $0.29 \mathrm{~g}$.

The conditions of the electrosynthesis procedure in the case of $\mathrm{Me}_{4} \mathrm{NBr}(99 \%$, Sigma-Aldrich) and $\mathrm{Et}_{4} \mathrm{NI}(98 \%$, Sigma-Aldrich) supporting salts were the same.

\subsubsection{Electrosynthesis of $\left[\mathrm{Zr}(\mathrm{Oct})_{\mathrm{x}}\right]$}

In total, $16 \mathrm{mg}\left(1 \times 10^{-4} \mathrm{~mol}\right)$ of $\mathrm{Et}_{4} \mathrm{NCl}$ and $2.0 \mathrm{~mL}\left(13 \times 10^{-3} \mathrm{~mol}\right)$ of octanoic acid were dissolved in $10 \mathrm{~mL}$ of acetonitrile.

Electrolysis was carried out at a constant voltage of $70 \mathrm{~V}$. The current was stable at $\sim 40 \mathrm{~mA}$. During the initial $25 \mathrm{~min}$ of electrolysis, the working solution was heated to $55^{\circ} \mathrm{C}$ and became turbid. The total electrolysis time was $320 \mathrm{~min}$. In the last $120 \mathrm{~min}$, the current gradually decreased. The working solution after electrolysis was left for $180 \mathrm{~min}$ to sediment. Then, the electrolyte was poured out of the cell; a yellow viscous liquid was obtained at its bottom. The liquid was dissolved in $\mathrm{CCl}_{4}$ and the obtained solution was passed through a $0.45 \mu \mathrm{m}$ PTFE filter. $\mathrm{CCl}_{4}$ was removed and the product was dried under reduced pressure and $80^{\circ} \mathrm{C}$. The yield was $0.70 \mathrm{~g}$.

\subsubsection{Electrosynthesis of $\left[\operatorname{Zr}(\operatorname{Laur})_{\mathrm{x}}\right]$}

In total, $16 \mathrm{mg}\left(1 \times 10^{-4} \mathrm{~mol}\right)$ of $\mathrm{Et}_{4} \mathrm{NCl}$ and $110 \mathrm{mg}\left(0.6 \times 10^{-3} \mathrm{~mol}\right)$ of lauric acid were dissolved in $10 \mathrm{~mL}$ of acetonitrile.

Electrolysis was carried out at a constant voltage of $80 \mathrm{~V}$. During the initial $10 \mathrm{~min}$ of electrolysis, the working solution was heated to $45^{\circ} \mathrm{C}$ and became turbid. After $15 \mathrm{~min}$ of electrolysis, the current started to decrease. The total electrolysis time was $35 \mathrm{~min}$. The product was obtained as a white plastic mass on the surface of the anode. The yield was $70 \mathrm{mg}$. 


\subsection{Chemical Synthesis of Zirconium Acetate}

In total, $2.33 \mathrm{~g}$ of $\mathrm{ZrCl}_{4}\left(10 \times 10^{-3} \mathrm{~mol}\right)$ was dissolved in $20 \mathrm{~mL}\left(350 \times 10^{-3} \mathrm{~mol}\right)$ of acetic acid [58]. The mixture was refluxed for $5 \mathrm{~h}$. Zirconium acetate formed as a white precipitate. Then it was dried under reduced pressure and $80{ }^{\circ} \mathrm{C}$. The yield was $2.98 \mathrm{~g}$.

Calc. for $\mathrm{Zr}\left(\mathrm{CH}_{3} \mathrm{COO}\right)_{4}\left(\mathrm{M}=327.4 \mathrm{~g} \cdot \mathrm{mol}^{-1}\right)$, wt\%: C, 29.4, H, 3.7, $\mathrm{Zr}, 27.9$; found: $\mathrm{C}, 26.9, \mathrm{H}, 3.4$, $\mathrm{Zr}, 30.5, \mathrm{Cl}, 1.2$.

${ }^{1} \mathrm{H}$ NMR and ${ }^{13} \mathrm{C}\left\{{ }^{1} \mathrm{H}\right\}$ NMR spectra of the chemically synthesized zirconium acetate are shown in Supplementary Materials.

\subsection{Ethylene Oligomerization}

Ethylene oligomerization was carried out in a $75 \mathrm{~mL}$ stainless steel autoclave with a magnetic stirrer inside and equipped with an electronic pressure sensor. Before the oligomerization process, the autoclave was dried under reduced pressure, purged and filled with nitrogen. During the oligomerization process, ethylene ( $\geq 99.95$ vol\%, Linde Gas, Munich, Germany) was continuously fed into the autoclave to maintain a constant pressure. A constant temperature in the autoclave was provided by a silicon oil bath.

Toluene (reagent grade) was used as a solvent; it was previously purified from traces of water by distillation in the presence of sodium and benzophenone. Ethylaluminium sesquichloride $\mathrm{Et}_{3} \mathrm{Al}_{2} \mathrm{Cl}_{3}$ ( $0.4 \mathrm{M}$ solution in hexane, ACROS Organics), ethylaluminum dichloride $\mathrm{EtAlCl}_{2}$ (1.0 $\mathrm{M}$ solution in hexanes, Sigma-Aldrich), diethylaluminum chloride $\mathrm{Et}_{2} \mathrm{AlCl}(1.0 \mathrm{M}$ solution in hexanes, Sigma-Aldrich) and triethylaluminum $\mathrm{AlEt}_{3}$ (1.0 M solution in hexanes, Sigma-Aldrich) were used as co-catalysts.

All manipulations for the preparation of solutions $(\mathrm{V}=25 \mathrm{~mL})$ of pre-catalyst $(20-40 \mu \mathrm{mol})$ and co-catalyst were carried out using the Schlenk system. After the addition of solution with a pre-catalyst and co-catalyst, the autoclave was weighed.

The oligomerization of ethylene was carried out for 30-60 min. After the oligomerization process, the autoclave was cooled to $-20^{\circ} \mathrm{C}$ (to condensate butenes) and unreacted ethylene was released. Then, the catalytic system was deactivated by the hydrolysis of aluminum co-catalyst with $2 \mathrm{~mL}$ of $5 \mathrm{vol} \%$ $\mathrm{HCl}$ solution in methanol. The autoclave was weighed to determine the amount of oligomers formed. The oligomerization activity A was calculated on the basis of the weight of oligomers formed using Equation (4):

$$
A=\frac{m_{\text {oligomer }}}{M_{\mathrm{C} 2 H 4} \times n_{\mathrm{Zr}} \times \tau}
$$

where $m_{\text {oligomer }}$ is the weight of oligomers, $\mathrm{g} ; M_{\mathrm{C} 2 \mathrm{H} 4}$ is the molar weight of ethylene, $28 \mathrm{~g} \cdot \mathrm{mol}^{-1} ; n_{\mathrm{Zr}}$ is the amount of pre-catalyst, $(20-40) \times 10^{-6} \mathrm{~mol}$; and $\tau$ is the reaction time, $0.5-1.0 \mathrm{~h}$. The oligomerization activity $\mathrm{A}$ is expressed in units $\left[\mathrm{mol}_{\mathrm{C} 2 \mathrm{H} 4} \cdot \mathrm{mol}_{\mathrm{Zr}}{ }^{-1} \cdot \mathrm{h}^{-1}\right]-(\mathrm{mol}$ of ethylene converted $) \times(\mathrm{mol} \mathrm{of} \mathrm{Zr})^{-1}$ $\times \mathrm{h}^{-1}$.

The reaction mixture was analyzed by GC-MS. According to the results of the GC-MS-analysis, in particular on the basis of the signals of 1-hexene, 1-octene and 1-dodecene and using calibrations with the standard mixtures of 1-hexene (97\%, ACROS Organics), 1-octene (99+\%, ACROS Organics) and 1-dodecene (93-95\%, ACROS Organics), the average Schulz-Flory parameter " $\alpha$ " was calculated and consequently the molecular weight distribution of oligomers was determined.

The amount of alkylbenzenes was calculated using results of GC-MS and calibrations with standard mixtures of 1-octene (99+\%, ACROS Organics) and ethylbenzene (laboratory reagent grade, Chemsnab-SPB, Russia).

\section{Conclusions}

The process of the electrochemical synthesis of zirconium carboxylates was studied. Using cyclic voltammetry, it was found that the halide anion acts as a mediator in the interaction of zirconium metal and carboxylic acid. 
The electrochemical synthesis of zirconium carboxylates was carried out. The electrochemical method is effective for producing zirconium acetate and octanoate (the productivity is $0.11-0.13 \mathrm{~g}$ per hour). In the case of lauric acid, its low solubility and the rapid covering of the anode surface by the product during electrolysis do not allow satisfactory yields of zirconium laurate to be obtained.

Using element analysis, NMR and IR spectroscopy and PXRD techniques, it was found that the obtained substances were amorphous non-stoichiometric zirconium carboxylates $\left[\mathrm{Zr}(\mathrm{Ac})_{\mathrm{x}}\right],\left[\mathrm{Zr}(\mathrm{Oct})_{\mathrm{x}}\right]$, [ $\left.\operatorname{Zr}(\text { Laur })_{\mathrm{x}}\right](3<\mathrm{x}<4)$ with a bidentate coordination of carboxylate moieties to zirconium.

The zirconium carboxylates in combination with an organoaluminium co-catalyst catalyze the homogeneous oligomerization and polymerization of ethylene. The characteristics of the product obtained strongly depend on the aluminum acidity, as well as on the $\mathrm{Al} / \mathrm{Zr}$ ratio. The zirconium carboxylates, which are activated by 10 eq. of $\mathrm{Et}_{3} \mathrm{Al}_{2} \mathrm{Cl}_{3}(\mathrm{Al} / \mathrm{Zr}=20)$, have an activity of $(7.6-9.9) \times 10^{3}$ $\mathrm{mol}_{\mathrm{C} 2 \mathrm{H} 4} \cdot \mathrm{mol}_{\mathrm{Zr}}{ }^{-1} \cdot \mathrm{h}^{-1}$ and selectivity to LAO of $78-85 \%\left(\mathrm{~T}=80^{\circ} \mathrm{C} ; \mathrm{p}=20\right.$ bar; $\left.\tau=60 \mathrm{~min}\right)$; finally, the $\mathrm{C}_{4}-\mathrm{C}_{10}$ fraction content in the oligomerization products is $72-89 \mathrm{wt} \%$.

Supplementary Materials: The following are available online at http://www.mdpi.com/2073-4344/9/12/1059/s1, Figure S1: Cyclic voltammograms, recorded on a Zr working electrode in an acetonitrile solution of (a) octanoic acid (1), octanoic acid $+\mathrm{Et}_{4} \mathrm{NCl}(2)$; (b) lauric acid (1), lauric acid $+\mathrm{Et}_{4} \mathrm{NCl}(2)$, Figure S2. ${ }^{1} \mathrm{H} \mathrm{NMR}$ spectrum of $\left[\mathrm{Zr}(\mathrm{Ac})_{\mathrm{x}}\right]$, Figure S3. ${ }^{1} \mathrm{H}$ NMR spectrum of $\left[\mathrm{Zr}(\mathrm{Oct})_{\mathrm{x}}\right]$, Figure S4. ${ }^{1} \mathrm{H}$ NMR spectrum of $\left[\mathrm{Zr}(\operatorname{Laur})_{\mathrm{x}}\right]$, Figure S5. ${ }^{13} \mathrm{C}\left\{{ }^{1} \mathrm{H}\right\}$ NMR spectrum of $\left[\mathrm{Zr}(\mathrm{Ac})_{\mathrm{x}}\right]$, Figure S6. ${ }^{13} \mathrm{C}\left\{{ }^{1} \mathrm{H}\right\}$ NMR spectrum of $\left[\mathrm{Zr}(\mathrm{Oct})_{\mathrm{x}}\right]$, Figure $\mathrm{S} 7 .{ }^{13} \mathrm{C}\left\{{ }^{1} \mathrm{H}\right\}$ NMR spectrum of $\left[\mathrm{Zr}(\text { Laur })_{x}\right]$, Figure S8. IR spectra of octanoic acid and $\left[\mathrm{Zr}(\mathrm{Oct})_{\mathrm{x}}\right]$. Figure S9. ${ }^{1} \mathrm{H}$ NMR spectrum of chemically synthesized zirconium acetate, Figure S10. ${ }^{13} \mathrm{C}\left\{{ }^{1} \mathrm{H}\right\}$ NMR spectrum of chemically synthesized zirconium acetate.

Author Contributions: Conceptualization and methodology of this study are initiated by G.E.B., S.V.K. and D.G.Y. The experimental work, discussion of the results, original draft preparation, review and editing belongs to G.E.B., A.V.S., A.M.K., K.R.K., A.V.G., I.V.V., S.V.K. and D.G.Y. Electrochemical study and catalytic experiments have been performed by G.E.B., A.V.S., A.M.K. and D.G.Y.

Funding: This work was funded by the Russian Government Program of Competitive Growth of Kazan Federal University (Reg. Nr. AAAA-A19-119053190012-8) and the Government assignment for FRC Kazan Scientific Center of RAS (Reg. Nr. AAAA-A18-118041760011-2).

Acknowledgments: The authors are thankful to the Russian Government Program of Competitive Growth of Kazan Federal University for financial support of performing of catalytic experiments in KFU, Government assignment for FRC Kazan Scientific Center of RAS for supporting of the electrochemical research and gratefully acknowledge the CSF-SAC FRC KSC RAS for providing necessary facilities to carry out this work.

Conflicts of Interest: The authors declare no conflict of interest.

\section{References}

1. Bugrova, T.A.; Dutov, V.V.; Svetlichnyi, V.A.; Corberán, V.C.; Mamontov, G.V. Oxidative dehydrogenation of ethane with $\mathrm{CO}_{2}$ over $\mathrm{CrO}_{x}$ catalysts supported on $\mathrm{Al}_{2} \mathrm{O}_{3}, \mathrm{ZrO}_{2}, \mathrm{CeO}_{2}$ and $\mathrm{Ce}_{\mathrm{x}} \mathrm{Zr}_{1-\mathrm{x}} \mathrm{O}_{2}$. Catal. Today 2019, 333, 71-80. [CrossRef]

2. Yarulina, I.; De Wispelaere, K.; Bailleul, S.; Goetze, J.; Radersma, M.; Abou-Hamad, E.; Vollmer, I.; Goesten, M.; Mezari, B.; Hensen, E.J.M.; et al. Structure-performance descriptors and the role of Lewis acidity in the methanol-to-propylene process. Nat. Chem. 2018, 10, 804-812. [CrossRef] [PubMed]

3. Kondratenko, V.A.; Hahn, T.; Bentrup, U.; Linke, D.; Kondratenko, E.V. Metathesis of ethylene and 2-butene over $\mathrm{MoO}_{\mathrm{x}} / \mathrm{Al}_{2} \mathrm{O}_{3}-\mathrm{SiO}_{2}$ : Effect of $\mathrm{MoO}_{\mathrm{x}}$ structure on formation of active sites and propene selectivity. J. Catal. 2018, 360, 135-144. [CrossRef]

4. Cornils, B.; Herrmann, W.A.; Beller, M.; Paciello, R. Oligomerization, Cyclooligomerization, Dimerization. In Applied Homogeneous Catalysis with Organometallic Compounds: A Comprehensive Handbook in Four Volumes; Wiley-VCH Verlag GmbH \& Co. KGaA: Weinheim, Germany, 2018; pp. 307-409.

5. Bianchini, C.; Giambastiani, G.; Luconi, L.; Meli, A. Olefin oligomerization, homopolymerization and copolymerization by late transition metals supported by (imino) pyridine ligands. Coord. Chem. Rev. 2010, 254, 431-455. [CrossRef]

6. Camara Greiner, E.O.; Inoguchi, Y. Chemical Economics Handbook. Linear Alpha-Olefins (681.5030); SRI Consulting: Menlo Park, CA, USA, 2010; p. 78. 
7. Stürzel, M.; Mihan, S.; Mülhaupt, R. From multisite polymerization catalysis to sustainable materials and all-polyolefin composites. Chem. Rev. 2016, 116, 1398-1433. [CrossRef]

8. Kaminsky, W. The Discovery of metallocene catalysts and their present state of the art. J. Polym. Sci. Part. A-1 Polym. Chem. 2004, 42, 3911-3921. [CrossRef]

9. Bryliakov, K.P.; Talsi, E.P. Frontiers of mechanistic studies of coordination polymerization and oligomerization of $\alpha$-olefins. Coord. Chem. Rev. 2012, 256, 2994-3007. [CrossRef]

10. Breuil, P.-A.R.; Magna, L.; Olivier-Bourbigou, H. Role of homogeneous catalysis in oligomerization of olefins: Focus on selected examples based on group 4 to group 10 transition metal complexes. Catal. Lett. 2015, 145, 173-192. [CrossRef]

11. Forestière, A.; Olivier-Bourbigou, H.; Saussine, L. Oligomerization of monoolefins by homogeneous catalysts. Oil Gas. Sci. Technol. Rev. IFP 2009, 64, 649-667. [CrossRef]

12. McGuinness, D.S. Olefin oligomerization via metallacycles: Dimerization, trimerization, tetramerization, and beyond. Chem. Rev. 2011, 111, 2321-2341. [CrossRef]

13. Aldoshin, S.M.; Troitskij, V.N.; Makhaev, V.D.; Matkovskij, P.E.; Petrova, L.A. Method of zirconium carboxylate production. Russian Patent 2332398, October 2006.

14. Wang, Y.; Huang, W.; Ma, H.; Huang, J. Ethylene-bridged $C_{1}$-symmetric ansa-(3-R-indenyl) (fluorenyl) zirconocene complexes for propylene dimerization or polymerization: The effect of $\mathrm{R}$ group. Polyhedron 2014, 76, 81-93. [CrossRef]

15. Arnold, T.A.Q.; Buffet, J.-C.; Turner, Z.R.; O'Hare, D. Synthesis, characterisation, and polymerisation studies of hexamethylindenyl zirconocenes and hafnocenes. J. Organomet. Chem. 2015, 792, 55-65. [CrossRef]

16. Aliev, V.; Moza, F.; Al'-Khazmi. Catalyst composition and method of producing linear alpha-olefins. Russian Patent 2456076, November 2008.

17. Al-Jarallah, A.M.; Anabtawi, J.A.; Siddiqui, M.A.B.; Aitani, A.M.; Al-Sa'doun, A.W. Ethylene dimerization and oligomerization to butene- 1 and linear $\alpha$-olefins: A review of catalytic systems and processes. Catal. Today 1992, 14, 1-121. [CrossRef]

18. Makhaev, V.D.; Petrova, L.A. Reactions of zirconium tetrachloride with pivalic acid in organic solvents under heating. Russ. J. Inorg. Chem. 2011, 56, 304-307. [CrossRef]

19. Kapoor, R.N.; Mehrotra, R.C. Organic compounds of zirconium. Part VI. Reactions of zirconium tetrachloride and iso-propxide with fatty acids. J. Chem. Soc. 1959, 422-426. [CrossRef]

20. Blumenthal, W.B. The Chemical Behavior of Zirconium; (Translation from English. Van Norstrand Co, New York-London-Toronto, 1958); Izdatel'stvo Inostrannoy Literatury: Moscow, Russia, 1963; pp. 280-290.

21. Paul, R.C.; Baidya, O.B.; Kumar, R.C.; Kapoor, R. Zirconium (IV) carboxylate. Aust. J. Chem. 1976, 29, 1605-1607. [CrossRef]

22. Ludwig, J.; Schwartz, D. Reactions of zirconium(IV) chloride with some aliphatic acids. Inorg. Chem. 1970, 9, 607-611. [CrossRef]

23. Kumar, N.; Tuck, D.G.; Watson, K.D. The direct electrochemical synthesis of some transition metal carboxylates. Can. J. Chem. 1987, 65, 740-743. [CrossRef]

24. Zhang, Q.; Li, H.; Liu, X.; Qin, W.; Zhang, Y.; Xue, W.; Yang, S. Modified porous Zr-Mo mixed oxides as strong acid catalysts for biodiesel production. Energy Technol. 2013, 1, 735-742. [CrossRef]

25. Wang, S.; Lee, J.S.; Wahiduzzaman, M.; Park, J.; Muschi, M.; Martineau-Corcos, C.; Tissot, A.; Cho, K.H.; Marrot, J.; Shepard, W.; et al. A robust large-pore zirconium carboxylate metal-organic framework for energy-efficient water-sorption-driven refrigeration. Nat. Energy 2018, 3, 985-993. [CrossRef]

26. Yan, C.; Liu, R.; Zhang, C.; Cao, Y. Zirconium carbide, hafnium carbide and their ternary carbide nanoparticles by an in situ polymerization route. RSC Adv. 2015, 5, 36520-36529. [CrossRef]

27. Xiao, L.; Johnson, K.E. Electrochemistry of 1-butyl-3-methyl-1H-imidazolium tetrafluoroborate ionic liquid. J. Electrochem. Soc. 2003, 150, E307-E311. [CrossRef]

28. Dzhardimalieva, G.I.; Pomogailo, A.D. Macromolecular metal carboxylates. Russ. Chem. Rev. 2008, 77, 259-301. [CrossRef]

29. AIST. Spectral Database for Organic Compounds SDBS Home Page. Available online: https://sdbs.db.aist.go. jp/sdbs/cgi-bin/cre_index.cgi (accessed on 24 October 2019).

30. Galakhov, M.V.; Heinz, G.; Royo, P. Intramolecular coordination of an alkene to a mixed dicyclopentadienyl benzyl zirconium cation studied by NMR spectroscopy. Chem. Commun. 1998, 1, 17-18. [CrossRef] 
31. Nelson, P.N.; Ellis, H.A.; White, N.A.S. Solid state ${ }^{13}$ C-NMR, infrared, X-ray powder diffraction and differential thermal studies of the homologous series of some mono-valent metal ( $\mathrm{Li}, \mathrm{Na}, \mathrm{K}, \mathrm{Ag}$ ) n-alkanoates: A comparative study. Spectrochim. ActaPart A 2015, 145, 440-453. [CrossRef]

32. Feio, G.; Burrows, H.D.; Geraldes, C.F.G.C.; Pinheiro, T.J.T. Multinuclear nuclear magnetic resonance, studies of lead(II) soaps Part 3-Studies on the liquid phase with reference to the behaviour of the corresponding acids. J. Chem. Soc. Faraday Trans. 1993, 89, 3117-3122. [CrossRef]

33. Saito, H. Conformation-dependent ${ }^{13} \mathrm{C}$ chemical shifts: A new means of conformational characterization as obtained by high-resolution solid-state 13C NMR. Magn. Reson. Chem. 1986, 24, 835-852. [CrossRef]

34. Burrows, H.D.; Miguel, M.d.G.; Pereira, R.P.C.; Proença, N.M.B.; Cardoso, S.M.C.; Geraldes, C.F.G.C.; Gil, M.H.; Brown, W. Solution behaviour of lead (II) carboxylates in organic solvents. Colloids Surf. A Physicochem. Eng. Aspects 2004, 250, 459-465. [CrossRef]

35. Feio, G.; Burrows, H.D.; Geraldes, C.F.G.C.; Pinheiro, T.J.T. Multinuclear NMR studies of lead (II) soaps II. ${ }^{13} \mathrm{C}$ and ${ }^{1} \mathrm{H}$ studies of solid and liquid-crystalline phases. Liq. Cryst. 1991, 9, 417-432. [CrossRef]

36. Martinez Casado, F.J.; Ramos Riesco, M.; Garcia Perez, M.V.; Redondo, M.I.; Lopez-Andres, S.; Rodriguez Cheda, J.A. Structural and thermodynamic study on short metal alkanoates: Lithium propanoate and pentanoate. J. Phys. Chem. B 2009, 113, 12896-12902. [CrossRef]

37. Corkery, R.W. A variation on Luzzati's soap phases. Room temperature thermotropic liquid crystals. Phys. Chem. Chem. Phys. 2004, 6, 1534-1546. [CrossRef]

38. Lin-Vien, D.; Colthup, N.B.; Fateley, W.G.; Grasselli, J.G. Infrared and Raman Characteristic Frequencies of Organic Molecules; Academic Press: San Diego, CA, USA, 1991; pp. 137-140.

39. Edwards, D.A.; Hayward, R.N. Transition metal acetates. Can. J. Chem. 1968, 46, 3443-3446. [CrossRef]

40. Nakamoto, K. Infrared Spectra of Inorganic and Coordination Compounds; Wiley: New York, NY, USA, 1963; pp. 90-106.

41. Deacon, G.B.; Phillips, R.J. Relationships between the carbon-oxygen stretching frequencies of carboxylato complexes and the type of carboxylate coordination. Coord. Chem. Rev. 1980, 33, 227-250. [CrossRef]

42. Marques, E.F.; Burrows, H.D.; da Miguel, M. The structure and thermal behaviour of some long chain cerium(III) carboxylates. J. Chem. Soc. Faraday Trans. 1998, 94, 1729-1736. [CrossRef]

43. Li, H.; Bu, W.; Qi, W.; Wu, L. Self-assembled multibilayers of europium alkanoates: Structure, photophysics, and mesomorphic behaviour. J. Phys. Chem. B 2005, 109, 21669-21676. [CrossRef]

44. Costa, A.M.A.; Burrows, H.D.; Geraldes, C.F.G.C.; Teixeira-Dias, J.J.C.; Bazuin, C.G.; Guillon, D.; Skoulios, A.; Blackmore, E.; Tiddy, G.J.T.; Turner, D.L. Mesophase formation in lead (II) decanoate. Liq. Cryst. 1986, 1, 215-226. [CrossRef]

45. Killian, C.M.; Johnson, L.K.; Brookhart, M. Preparation of linear $\alpha$-olefins using cationic nickel (II) $\alpha$-diimine catalysts. Organometallics 1997, 16, 2005-2007. [CrossRef]

46. Britovsek, G.J.P.; Malinowski, R.; McGuinness, D.S.; Nobbs, J.D.; Tomov, A.K.; Wadsley, A.W.; Young, C.T. Ethylene oligomerization beyond Schulz-Flory distributions. ACS Catal. 2015, 5, 6922-6925. [CrossRef]

47. Zhang, J.; Liu, S.; Li, A.; Ye, H.; Lib, Z. Nickel (II) complexes chelated by 2,6-pyridinedicarboxamide: Syntheses, characterization, and ethylene oligomerization. New J. Chem. 2016, 40, 7027-7033. [CrossRef]

48. Johnson, L.K.; Killian, C.M.; Brookhart, M. New Pd (II)- and Ni (II)-based catalysts for polymerization of ethylene and $\alpha$-olefins. J. Am. Chem. Soc. 1995, 117, 6414-6415. [CrossRef]

49. De Souza, R.F.; Bernardo-Gusmão, K.; Cunha, G.A.; Loup, C.; Leca, F.; Réau, R. Ethylene dimerization into 1-butene using 2-pyridylphosphole nickel catalysts. J. Catal. 2004, 226, 235-239. [CrossRef]

50. Svejda, S.A.; Brookhart, M. Ethylene oligomerization and propylene dimerization using cationic ( $\alpha$-diimine) nickel (II) catalysts. Organometallics 1999, 18, 65-74. [CrossRef]

51. Busca, G. Catalytic materials based on silica and alumina: Structural features and generation of surface acidity. Prog. Mater. Sci. 2019, 104, 215-249. [CrossRef]

52. Bruno, J.E.; Dooley, K.M. Double-bond isomerization of hexadecenes with solid acid catalysts. Appl. Catal. A 2015, 497, 176-183. [CrossRef]

53. Matkovskii, P.E.; Irzhak, V.I.; Mel'nikov, V.N. Optimization of hexene-1 yield in the course oligomerization of ethylene on zirconium-containing complex catalysts. High. Mol. Weight Compd. 1993, 35, 207-211. (In Russian)

54. Aliev, V.; Moza, F.; Al'-Khazmi, M. Catalyst composition for oligomerisation of ethylene, oligomerisation method and method of producing catalyst composition. Russian Patent 2462309, November 2008. 
55. Matkovskii, P.E.; Moussalli, G.; Bölt, H.; Peter-Matthias, F. Catalytic system for oligomerization of ethylene to linear alpha-olefins. Russian Patent 2117012, June 1997.

56. Zhukov, V.I.; Val'kovich, G.V.; Skorik, I.N.; Petrov, Y.M.; Belov, G.P. Ethylene oligomerization in the presence of $\mathrm{ZrO}(\mathrm{OCOR})_{2}-\mathrm{Al}\left(\mathrm{C}_{2} \mathrm{H}_{5}\right)_{2} \mathrm{Cl}$-modifier catalytic system. Pet. Chem. 2007, 47, 49-54. [CrossRef]

57. Schöniger, W. Eine mikroanalytische Schnellbestimmung von halogen in organischen substanzen. Mikrochim. Acta 1955, 1, 123-129. [CrossRef]

58. Rosenheim, A.; Hertsmann, J. Zirkoniumtetrachlorid und kolloidales zirkoniumhydroxyd. Ber. Dtsch. Chem. Ges. 1907, 40, 810-814. [CrossRef]

(C) 2019 by the authors. Licensee MDPI, Basel, Switzerland. This article is an open access article distributed under the terms and conditions of the Creative Commons Attribution (CC BY) license (http://creativecommons.org/licenses/by/4.0/). 